\title{
Impact of Heat Transfer Media on Performance of Solar-Hydrogen Power Generation
}

\author{
Akira Nishimura1, Satoshi Kitagawa1, Masafumi Hirota1, Eric $\mathrm{Hu}^{2}$ \\ ${ }^{1}$ Division of Mechanical Engineering, Graduate School of Engineering, Mie University, Tsu, Japan \\ ${ }^{2}$ School of Mechanical, The University of Adelaide, Adelaide, Australia \\ Email: nisimura@mach.mie-u.ac.jp
}

How to cite this paper: Nishimura, A. Kitagawa, S., Hirota, M. and Hu, E. (2017) Impact of Heat Transfer Media on Performance of Solar-Hydrogen Power Generation. Smart Grid and Renewable Energy, 8, 351-365.

https://doi.org/10.4236/sgre.2017.812023

Received: November 21, 2017

Accepted: December 16, 2017

Published: December 21, 2017

Copyright () 2017 by authors and Scientific Research Publishing Inc. This work is licensed under the Creative Commons Attribution International License (CC BY 4.0).

http://creativecommons.org/licenses/by/4.0/

\begin{abstract}
Solar-hydrogen system has great potential for contributing to sustainable and clean energy supply. The aim of this study is to clarify the impact of heat transfer media in solar collector such as methane, ammonium, hydrogen, air and water on the performance of solar-hydrogen system. After estimating the highest temperature attainable by each heat transfer media, the amount of thermal energy that could be saved in the production of hydrogen or preheat for power generation by fuel cell was calculated. The power generation performance of fuel cell using each heat transfer media was also investigated. As a result, it has been revealed that the temperature changes of methane, ammonium and air follow the horizontal solar radiation intensity irrespective of seasons, and their highest temperatures are almost the same among them. The temperature response of hydrogen is slower than methane, ammonium and air. This study defines the ratio of saving thermal energy which indicates the effect of solar thermal utilization for production of hydrogen or preheat for power generation by fuel cell without using utility gas. It has been found that the biggest thermal energy saving is obtained when hydrogen and air are used as the heat transfer media. The power generated by PEFC system per effective area of evacuated tube collector in the case of using methane or ammonium is $3.309 \times 10^{-2} \mathrm{kWh} / \mathrm{m}^{2}$ and $2.076 \times 10^{-2} \mathrm{kWh} / \mathrm{m}^{2}$, respectively, while it is $2.466 \times 10^{-2} \mathrm{kWh}$ in the case of using hydrogen and air.
\end{abstract}

\section{Keywords}

Solar Collector, Heat Transfer Media, Heat Transfer, Solar-Hydrogen System, Fuel Cell

\section{Introduction}

Renewable energy such as solar thermal energy has great potential to contribute 
for sustainable and clean energy supply.

Utilization of solar thermal energy for hydrogen production is also promising technology. Hydrogen can be used for power generation in fuel cells which discharge only water. Therefore, the solar thermal hydrogen system is a clean and sustainable energy supply system. Many researches on such a solar-hydrogen system were reported recently. Water splitting cycle using terbium oxide [1], ceria zirconia solid solution [2], zinc oxide-zinc sulfate [3] and samarium and erbium oxide [4] with solar thermal energy were evaluated by means of solar-to-fuel conversion efficiency. These researches focused on water splitting technology and thermodynamic characteristics of each material for water splitting. The solar thermal energy is used for the thermochemical reaction. Therefore, it is necessary to find the water splitting cycle operated with lower heat input. The system consisting of water electrolysis with solar thermal energy was investigated from the viewpoint of energy and exergy efficiency [5] [6] [7]. M The evaluation of energy and exergy efficiency is important to develop these technologies since the effective utilization of solar thermal energy is needed. In addition, catalytic steam reforming using solar thermal energy for biogas [8], propane [9] and methanol [10]-[15] attracted attention recently. In these researches, the catalytic reaction is carried out by endothermic reaction, resulting that solar thermal energy is used for the reaction. The performance of catalytic steam reforming technology is influenced by the catalyst and reactor design. Furthermore, the operation temperature is influenced by the type of fuel such as biogas, propane and methanol. Therefore, the optimization of catalyst type, reactor size and operation temperature is very important. The researches [10]-[15] were evaluated by means of methanol conversion or temperature distribution in the reactor, which were conducted for reactor development. Since energy management is also important, the effective procedure to collect solar thermal should be developed. In these solar-hydrogen systems, various solar collectors are used. There are many types of solar collector, i.e., parabolic dish, parabolic trough, flat plate and evaluated tube collectors and so on, for utilization of solar thermal energy. Exergy analysis of many types of solar thermal collectors and processes was reported [16]. Heat transfer analysis by numerical model for novel all-glass evacuated tube solar collector manifold header with an inserted tube [17], evacuated tube solar air collector [18], façade integrated solar concentrator [19], metal corrugated packing solar air collector [20] and flat plate solar air collector [21] was conducted to clarify the heat transfer mechanism and the outlet temperature of solar collector. The system integrated with phase change material [22] [23] and adoption of nanofluids into water as heat transfer fluids [24] [25] [26] [27] [28] were adopted to promote the thermal performance of solar collector.

Although the research on solar-hydrogen system using solar collector has been reported well, there is few research to investigate the effect of heat transfer media used in the solar collector on the system performance. In this paper, such effects with methane, ammonium, hydrogen, air and water as the heat transfer 
media were investigated using the meteorological data of the project "PV300" (period from August, 2013 to July, 2014 [29]). The evacuated tube collector was considered as the solar collector in this study. After estimating the highest temperature could be attained by each heat transfer media, the amount of saving thermal energy to produce hydrogen was calculated for methane and ammonium. In addition, the amount of saving thermal energy to preheat for power generation by fuel cell was also calculated for hydrogen and air. Water was investigated as a reference media. This study defines the ratio of saving thermal energy $(R)$ which indicates the effect of solar thermal utilization for production of hydrogen or preheat for power generation by fuel cell without using utility gas. Finally, the power generation performance of fuel cell using each heat transfer media was also investigated.

\section{Analysis and Assessment}

\subsection{Heat Transfer Model of Solar Collector}

In this study, the commercial evacuated tube collector SOLARIS CPC1518 produced by Terada Tekkosyo [30] has been considered. Figure 1 and Table 1 show schematic drawing and specification, respectively. This evacuated tube collector is suitable for gases and liquids as heat transfermedia.

The temperature of heat transfer media in the evacuated tube collector is calculated by the following equation:

$$
Q(t+d t)=I(t+d t) \times A=c_{i} G_{i}\left\{T_{i}(t+d t)-T_{i}(t)\right\}+Q_{\text {loss }}(t+d t)
$$

where $Q$ is thermal heat by solar irradiation (kJ), $I$ is horizontal solar radiation referred by PV300 [29] $\left(\mathrm{kJ} / \mathrm{m}^{2}\right), A$ is effective area of evacuated tube collector $\left(\mathrm{m}^{2}\right), c_{i}$ is specific heat of heat transfermedia in evacuated tube collector

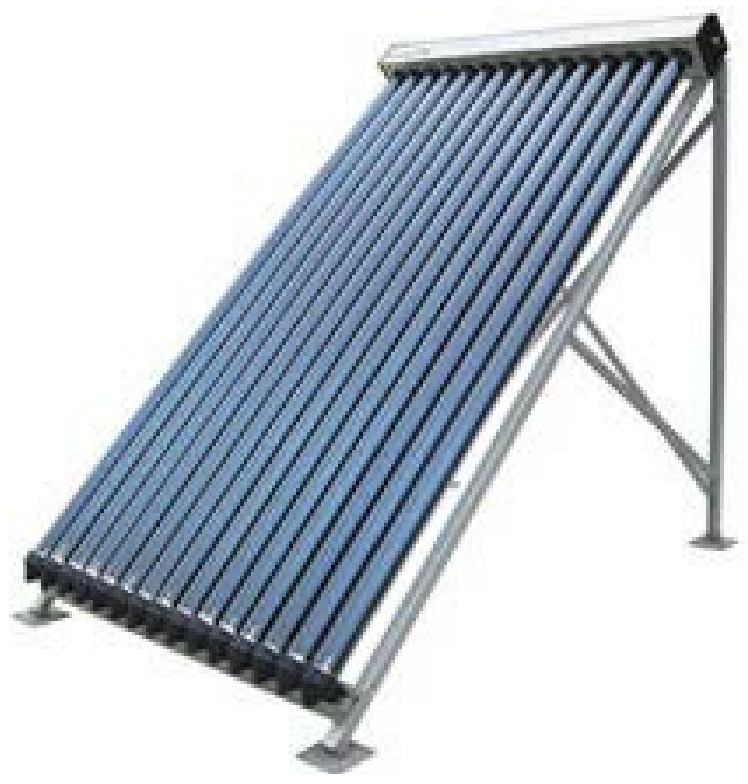

Figure 1. Schematic drawing of SOLARIS CPC1518. 
Table 1. Specification of SOLARIS CPC1518.

\begin{tabular}{cc}
\hline Number of glass tube & 18 \\
\hline Size & $2.08 \mathrm{~m} \times 1.64 \mathrm{~m} \times 0.1 \mathrm{~m}$ \\
Effective area & $3.0 \mathrm{~m}^{2}$ \\
Volume & $2.4 \times 10^{-3} \mathrm{~m}^{3}$ \\
Weight & $54 \mathrm{~kg}$ \\
Size of each glass tube & $47 \mathrm{~mm}$ (O.D.), $33 \mathrm{~mm}$ (I.D.), $1500 \mathrm{~mm}$ (L.) \\
\hline
\end{tabular}

$(\mathrm{kJ} /(\mathrm{kg} \cdot \mathrm{K})), G_{i}$ is total mass of heat transfermedia fulfilling evacuated tube collector $(\mathrm{kg}), T_{i}$ is temperature of heat transfer media in evacuated tube collector $(\mathrm{K})$ and $Q_{\text {loss }}$ is heat loss due to thermal convection and radiation $(\mathrm{kJ})$. It is assumed that $T_{\mathrm{i}}(0)=293 \mathrm{~K}$ when $t=0 \mathrm{~s} \cdot d t$ is time interval of $10 \mathrm{~s} \cdot Q_{\text {loss }}$ is calculated by the following equation:

$$
\begin{aligned}
Q_{\text {loss }}(t+d t)= & h A\left\{T_{i}(t+d t)-T_{\text {air }}(t+d t)\right\} d t \\
& +A \sigma \varepsilon F_{c \rightarrow \text { air }}\left[\left\{T_{i}(t+d t)\right\}^{4}-\left\{T_{\text {air }}(t+d t)\right\}^{4}\right] d t
\end{aligned}
$$

Where $h$ is heat transfer coefficient $\left(\mathrm{W} /\left(\mathrm{m}^{2} \cdot \mathrm{K}\right), T_{\text {air }}\right.$ is ambient air temperature referred by PV300 [29] (K), $\sigma$ is Stefan-Boltzmann constant $\left(=5.670 \times 10^{-11}\right)$ $\left(\mathrm{kW} /\left(\mathrm{m}^{2} \cdot \mathrm{K}^{4}\right)\right), \varepsilon$ is the emissivity of glass from $293 \mathrm{~K}$ to $373 \mathrm{~K}(=0.92)[31](-)$ and $F_{c \rightarrow \text { air }}$ is the shape factor from evacuated tube collector to ambient air (= 1) (-). $h$ is calculated by the following empirical equation on forced thermal convection for laminar flow over flat plate [32]:

$$
\begin{gathered}
N u=\frac{h l}{k_{\text {air }}}=0.664 \operatorname{Re}^{1 / 2} \operatorname{Pr}^{1 / 3},\left(0<\operatorname{Re} \leq 5 \times 10^{5}\right) \\
\operatorname{Re}=\frac{p u D}{\mu}
\end{gathered}
$$

where $l$ is length of evacuated glass tube $(=1.5)(\mathrm{m}), k_{\mathrm{air}}$ is thermal conductivity of air $(\mathrm{W} /(\mathrm{m} \cdot \mathrm{K})), \rho$ is density of air $\left(\mathrm{kg} / \mathrm{m}^{3}\right), u$ is velocity of air surrounding evacuated tube collector referred by PV 300 [29] (m/s), $D$ is outside diameter of evacuated glass tube $(=0.037)(\mathrm{m})$ and $\mu$ is viscosity of air $(\mathrm{Pa} \cdot \mathrm{s}) . k_{\mathrm{air}}, \rho, \mu$ and Prare assumed to be $2.57 \times 10^{-2} \mathrm{~W} /(\mathrm{m} \cdot \mathrm{K}), 1.166 \mathrm{~kg} / \mathrm{m}^{3}, 1.822 \times 10^{-5} \mathrm{~Pa} \cdot \mathrm{s}$ and 0.717 , respectively, which are values at $293 \mathrm{~K}$ [33]. In this study, the highest $u$ is $5.5 \mathrm{~m} / \mathrm{s}$, resulting that the maximum Re is 12,608 .

In this study, the following assumptions were made:

1) The natural convection of heat transfer media in evacuated glass tube is neglected. Since the temperature rise of heat transfer media is not high, the driving force of natural convection, which is density change of heat transfer media, is thought to be small.

2) There is no temperature distribution of heat transfer media in evacuated glass tube. Since the volume of evacuated glass tube is small which is $2.4 \times 10^{-3}$ $\mathrm{m}^{3}$, it is thought that the temperature distribution of heat transfer media in evacuated glass tube is small. 
3) There is no temperature distribution in evacuated glass tube. Since the thickness of evacuated glass tube is small which is $7 \mathrm{~mm}$, it can be thought that the temperature distribution in evacuated glass tube is small.

4) The temperature of evacuated glass tube is the same as the temperature of heat transfer media. As mentioned above, the thickness of evacuated glass tube is small which is $7 \mathrm{~mm}$. Therefore, it can be thought that the temperature of evacuated glass tube equals to the temperature of heat transfer media in evacuated glass tube.

4) The physical properties of heat transfer media are constant, which keep the values at $293 \mathrm{~K}$. Though the physical properties of heat transfer media, i.e., specific heat, considered in this study is changed with temperature, it is small. For example, the specific heats of air at $293 \mathrm{~K}$ and $353 \mathrm{~K}$ are $1.005 \mathrm{~kJ} /(\mathrm{kg} \cdot \mathrm{K})$ and $1.010 \mathrm{~kJ} /(\mathrm{kg} \cdot \mathrm{K})$, respectively [33]. Therefore, it can be thought that the physical properties of heat transfer media keep constant.

5) The pump energy loss for transporting heat transfer media is ignored. If the total energy balance and efficiency in the whole system are evaluated, the pump energy loss for transporting heat transfer media should be considered. However, the aim of this study is to evaluate the ratio of saving thermal energy which indicates the effect of solar thermal utilization for production of hydrogen or preheat for power generation by fuel cell without using utility gas. Then, this study focuses on temperature and required thermal energy of heat transfer media in evacuated glass tube, reactor and preheater for evaluation of saving thermal energy. The consideration of pump energy loss for transporting heat transfer media is the future work in this study.

The initial calculation parameters of numerical calculation are set as follows:

1) $T_{i}$ is $293 \mathrm{~K}$.

2) $T_{\text {air }}$ is $293 \mathrm{~K}$.

3) $C_{i}$ at $293 \mathrm{~K}$ is used.

4) The physical properties of air surrounding evacuated glass tube at $293 \mathrm{~K}$ are used.

Table 2 lists the specific heat of heat transfer media and mass of heat transfer media fulfilling the whole evacuated tube collector.

\subsection{Estimation Procedure of Saving Thermal Energy}

In this study, two cases are considered for solar-hydrogen system which are shown in Figure 2.

As to the first case, methane or ammonium is used as heat transfer media. After preheated in the evacuated tube collector, methane reacting with water (i.e., steam) in the reactor which is reformed into hydrogen, and ammonium is decomposed into hydrogen and nitrogen. Methane reacts with steam at temperature between $873 \mathrm{~K}$ and $1273 \mathrm{~K}$, in the presence of a catalyst; e.g., nickel [34] [35] [36]. Therefore, this study considers the methane reforming reactor operated at $1073 \mathrm{~K}$ which is kept by a gas combustor. Since the methane is preheated 
Table 2. Specific heat of heat transfer media and mass of heat transfer media fulfilling the whole evacuated tube collector.

\begin{tabular}{ccc}
\hline Heat transfer media & Specific heat $c_{\mathrm{i}}(\mathrm{kJ} /(\mathrm{kg} \cdot \mathrm{K}))$ & $\begin{array}{c}\text { Mass of heat transfer media fulfilling } \\
\text { the whole evacuated tube collector }(\mathrm{kg})\end{array}$ \\
\hline Methane & 2.206 & $1.558 \times 10^{-2}$ \\
Ammonium & 2.200 & $1.487 \times 10^{-2}$ \\
Hydrogen & 14.34 & $1.882 \times 10^{-3}$ \\
Air & 1.006 & $2.769 \times 10^{-2}$ \\
Water & 4.182 & 23.71 \\
\hline
\end{tabular}

Case 1 (methane, ammonium)

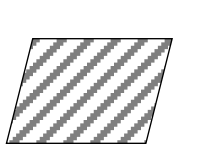

Evacuated tube collector

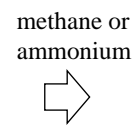

Reactor for methane steam reforming or ammonium decomposition
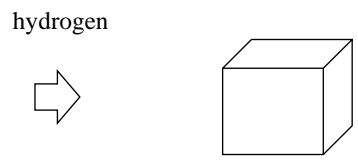

Fuel cell

Case 2 (hydrogen, air)
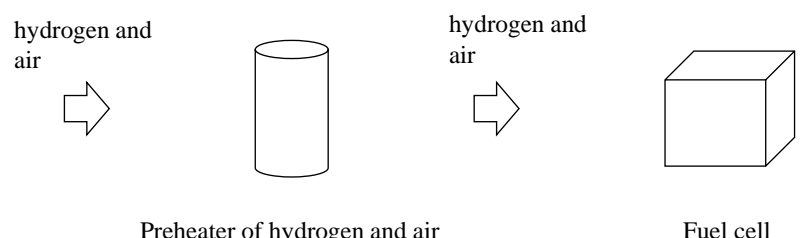

Fuel cell

Figure 2. System flow.

by solar thermal energy, the utility gas can be saved. The amount of heat needed from the utility gas is calculated by the following equation:

$$
Q^{\prime}=c_{i} G_{i}\left(T_{r}-T_{i}^{\prime}\right)
$$

where $Q^{\prime}$ is the amount of heat needed from room temperature or temperature preheated by evacuated tube collector to the reforming temperature (kJ), $T_{r}$ is reforming temperature $(K)$ and $T_{i}^{\prime}$ is room temperature or temperature of heat transfer media preheated by evacuated tube collector $(K)$. If the $Q^{\prime}$ is divided by the lower heating value of methane which is the main component of utility gas of $50.01 \mathrm{MJ} / \mathrm{kg}$, the amount of utility gas needed for attaining the reforming temperature is derived.

In the case of ammonium, the ammonium is decomposed into hydrogen and nitrogen fully at the temperature over $923 \mathrm{~K}$ [37]. Therefore, this study considers the ammonium decomposition reactor operated at $923 \mathrm{~K}$ which is kept by the combustion of utility gas. The amount of utility gas needed for attaining the decomposition temperature is calculated by Equation (5) and the lower heating value of the utility gas of $50.01 \mathrm{MJ} / \mathrm{kg}$.

In the second case, hydrogen and air are used as heat transfer media. After heated in the evacuated tube collector, hydrogen and air are provided for fuel 
cell. In this study, polymer electrolyte fuel cell (PEFC) was considered as typical fuel cell system. Generally, PEFC is operated at $353 \mathrm{~K}$ [38]. Therefore, this study considers the PEFC system operated at $353 \mathrm{~K}$ which is normally maintained by the hydrogen and air heated by the combustion of utility gas. Since hydrogen and air are preheated by solar thermal energy in our case, the utility gas can be saved. The amount of heat needed from the utility gas is calculated by the following equation:

$$
Q^{\prime \prime}=c_{i} G_{i}\left(T_{f}-T_{i}^{\prime}\right)
$$

where $Q^{\prime \prime}$ is the amount of heat needed from room temperature or temperature preheated by evacuated tube collector to operation temperature of PEFC system $(\mathrm{kJ})$ and $T_{f}$ is operation temperature of PEFC system $(=353)(\mathrm{K})$. If the $Q^{\prime \prime}$ is divided by the lower heating value of the utility gas of $50.01 \mathrm{MJ} / \mathrm{kg}$, the amount of utility gas needed for attaining the operation temperature of PEFC system is derived.

\subsection{Estimation Procedure of Power Generation by Fuel Cell}

It has been assumed that the $\mathrm{H}_{2}$ would be used to generate power through PEFC system. $\mathrm{H}_{2}$ is converted into electricity in fuel cell following the reaction below:

$$
\mathrm{H}_{2}+1 / 2 \mathrm{O}_{2}=\mathrm{H}_{2} \mathrm{O}+\eta_{f} \mathrm{H}
$$

where $\eta_{f}$ is power generation efficiency of latest PEFC stationary system based on lower heating value $(=0.39)$ [39], $H$ is lower heating value of $\mathrm{H}_{2}(=242)$ $(\mathrm{kJ} / \mathrm{mol})$. It is assumed that the energy loss for operating pump to preserve and provide gases is ignored.

\section{Results and Discussion}

\subsection{Impact of Heat Transfer Media on the Temperature out of Solar Collector}

As described in earlier section, this study has investigated the performance of evacuated tube collector with various heat transfer media using the meteorological data base of PV300 [29] including air temperature, solar intensity and wind speed at $10 \mathrm{sec}$ intervals. January, April, July and October were selected as the months which are representative of four seasons, respectively. Temperature change of heat transfer media in the evacuated tube collector with time was estimated for the standard day in the month with the mean amount of horizontal solar radiation of the month using the meteorological data base of PV300 [29].

Figures 3-6 show temperature change of heat transfer media in evacuated tube collector in daytime for January, April, July and October, respectively. Horizontal solar radiation intensity is also shown in these figures. Table 3 lists the highest temperature for each heat transfer media shown in Figures 3-6.

According to Figures 3-6, temperature changes of methane, ammonium and air follow the horizontal solar radiation intensity irrespective of seasons, and their highest temperatures are almost the same. The temperature change of 
Air - Water $\cdot \mathrm{NH}_{3} \cdot \mathrm{H}_{2} \cdot \mathrm{CH}_{4}-$ Horizontal solar radiation intensity

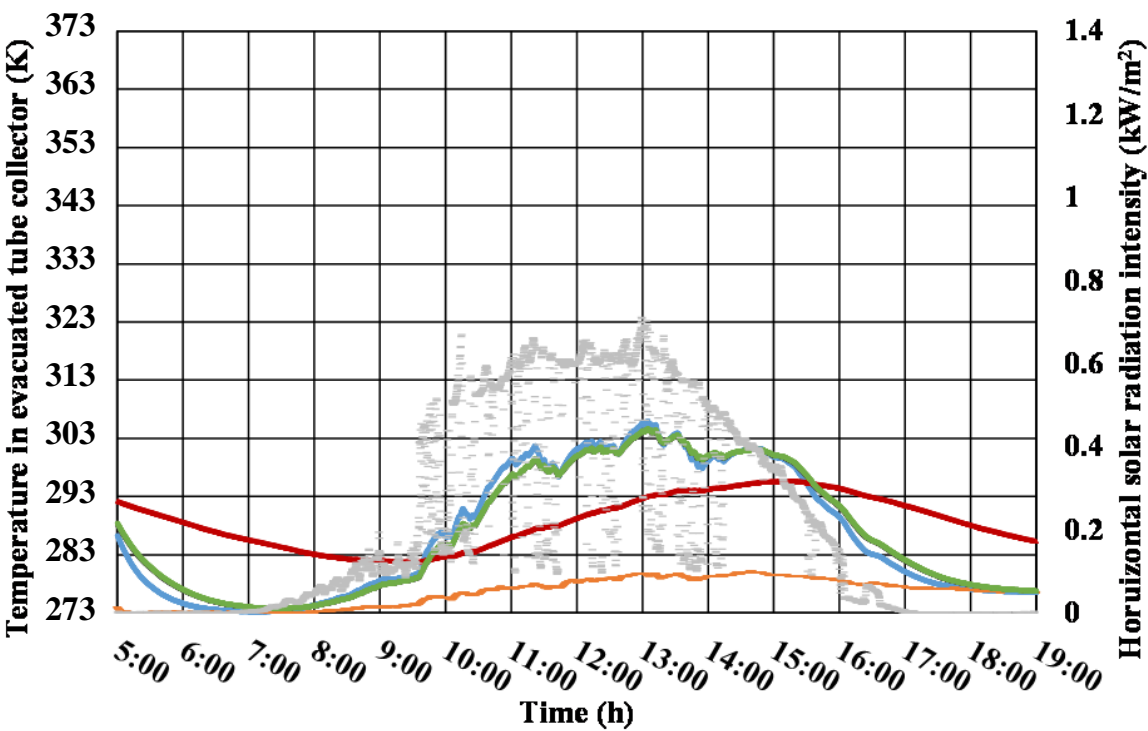

Figure 3. Temperature change of heat transfer media in evacuated tube collector in daytime for January.

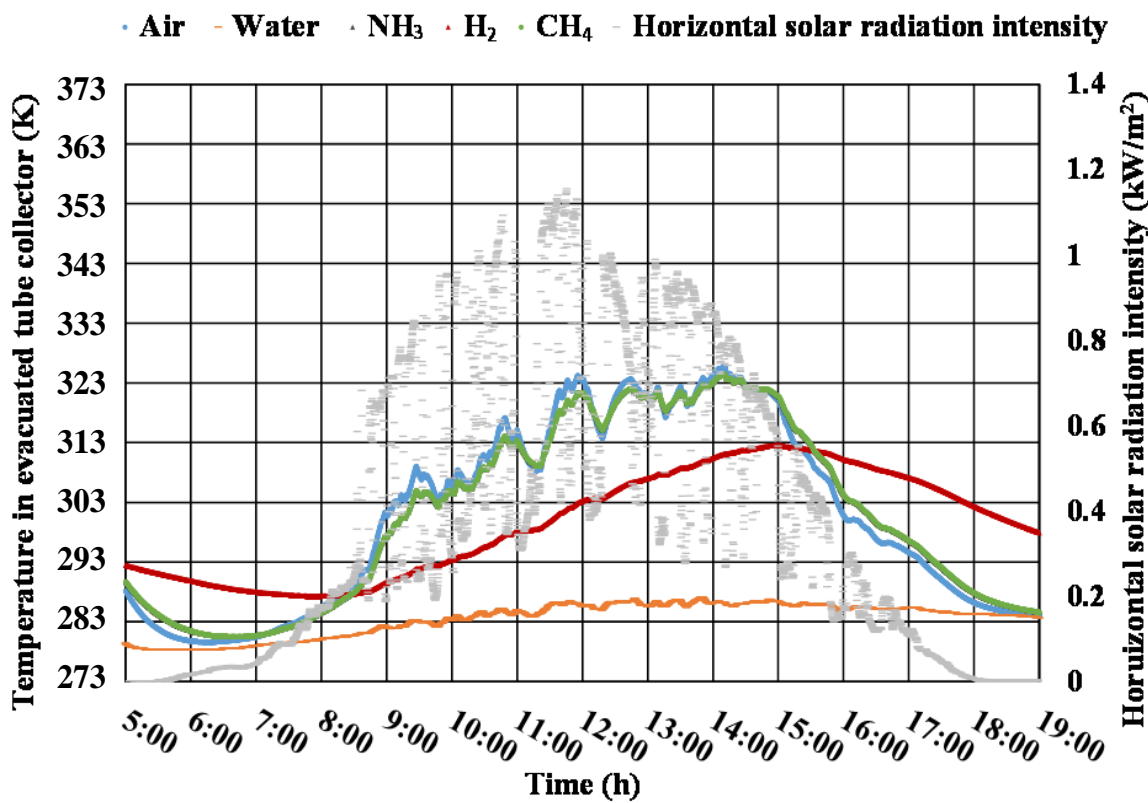

Figure 4. Temperature change of heat transfer media in evacuated tube collector in daytime for April.

methane, air and ammonium are influenced by the change in horizontal solar radiation intensity with time strongly since the specific heats of them are small. The temperature change and the maximum temperature in the evacuated tube collector for water are smaller compared to the other heat transfer media irrespective of seasons. Since the mass and specific heat of water inside the evacuated tube collector is larger than the other heat transfer media, the temperature of water changes slower with time and does not rise so high. In addition, the 
$\cdot$ Air - Water $\triangle \mathrm{NH}_{3} \cdot \mathrm{H}_{2} \cdot \mathrm{CH}_{4}-$ Horizontal solar radiation intensity

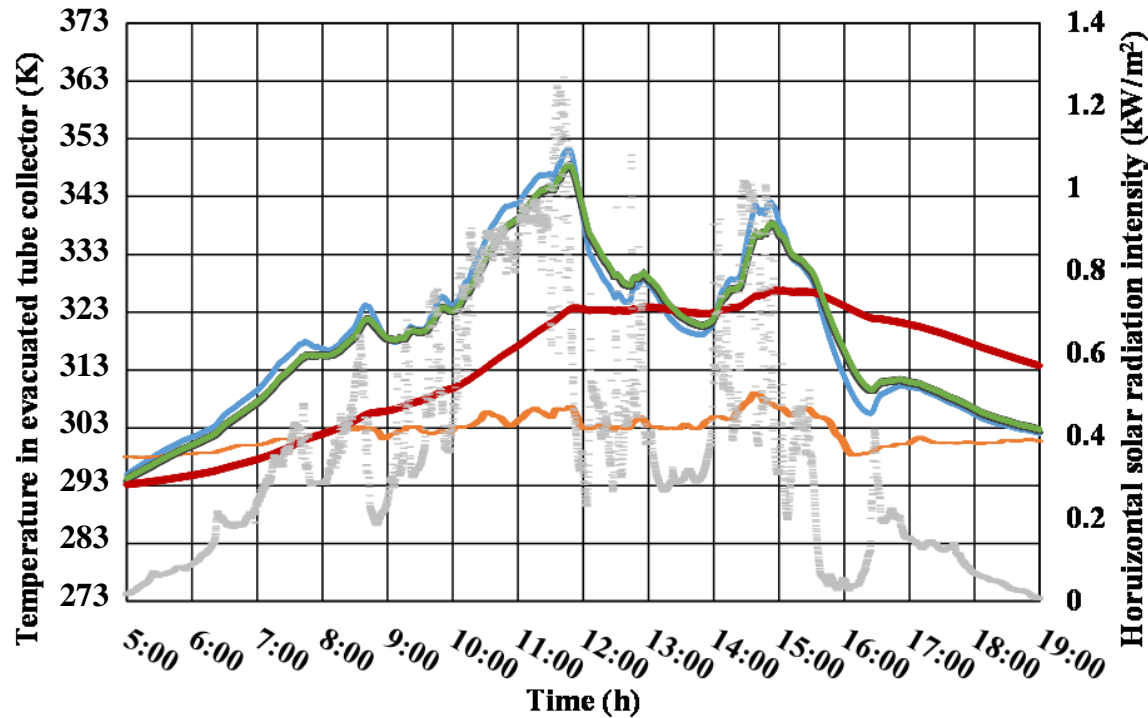

Figure 5. Temperature change of heat transfer media in evacuated tube collector in daytime for July.

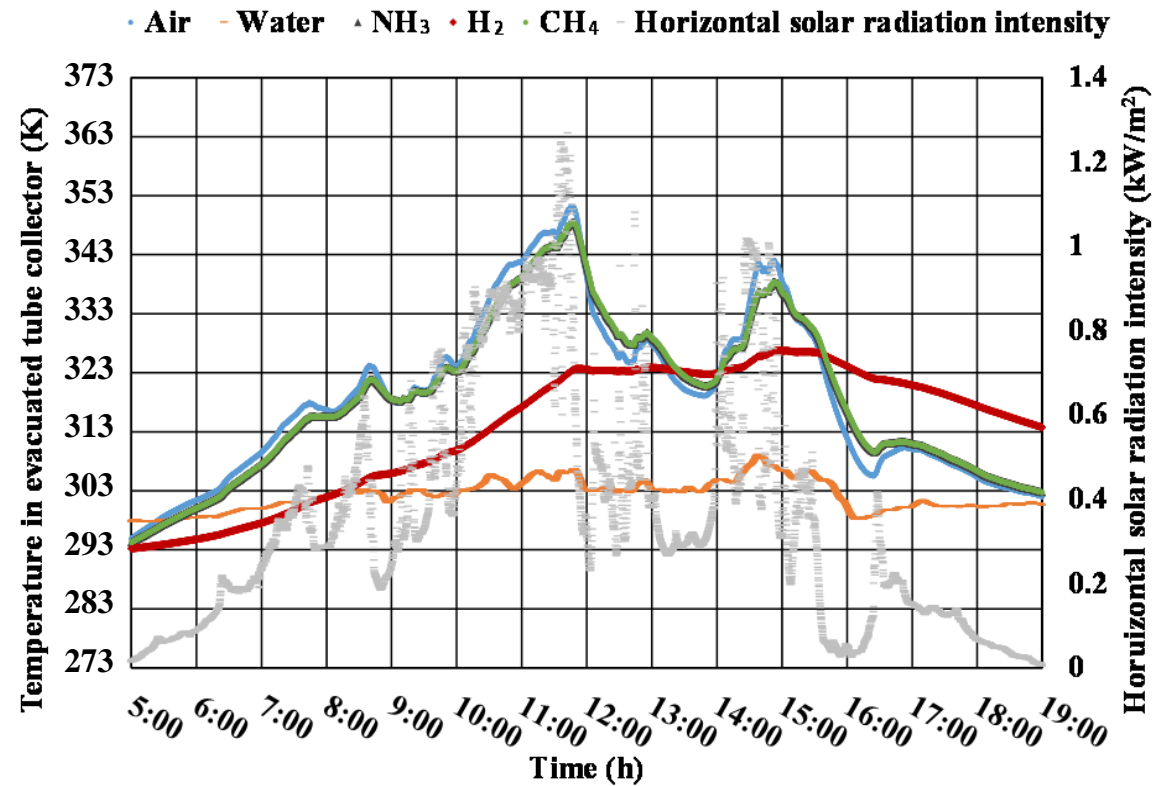

Figure 6. Temperature change of heat transfer media in evacuated tube collector in daytime for October.

Table 3. The highest temperature for each heat transfer media shown in Figures 3-6.

\begin{tabular}{ccccc}
\hline & January & April & July & October \\
\hline Methane (K) & 306 & 325 & 348 & 320 \\
Ammonium (K) & 306 & 325 & 348 & 320 \\
Hydrogen (K) & 297 & 313 & 327 & 311 \\
Air (K) & 307 & 326 & 351 & 321 \\
Water (K) & 301 & 287 & 308 & 298 \\
\hline
\end{tabular}


temperature rise and drop of hydrogen are slower than methane, ammonium and air. Since the specific heat of hydrogen is larger than the other heat transfer media, the temperature response of hydrogen is slower.

\subsection{Evaluation of Saving Thermal Energy and Power Generation by Fuel Cell}

In the case of using methane or ammonium as heat transfer media, $Q^{\prime}$, the thermal energy from utility gas required, was calculated by Equation (5). When methane is heated from the room temperature of $293 \mathrm{~K}$ to the reforming temperature of $1073 \mathrm{~K}$ per the mass of methane in an evacuated tube collector, $Q^{\prime}$ is $26.81 \mathrm{~kJ}$, which is equivalent to the needed utility gas indicated by $M$ of $5.361 \times 10^{-4} \mathrm{~kg}$. On the other hand, when ammonium is heated from the room temperature of $293 \mathrm{~K}$ to the decomposition temperature of $923 \mathrm{Kper}$ the mass of ammonium in an evacuated tube collector, $Q^{\prime}$ is $20.61 \mathrm{~kJ}$, which is equivalent to $M$ of $4.121 \times 10^{-4} \mathrm{~kg}$. However, if solar-hydrogen system is used, i.e., the heat transfer media is preheated in solar collector first then heated by the utility gas, the $Q^{\prime}$ required would be much less. Table 4 lists $Q^{\prime}, M$ and $R(\%)$ in the case of using methane or ammonium in solar-hydrogen system. From this table, $R$ of methane for January, April, July and October is 1.67\%, 4.10\%, 7.05\% and 3.46\%, respectively. On the other hand, $R$ of ammonium for January, April, July and October is $2.06 \%, 5.0 \%, 8.73 \%$ and $4.29 \%$, respectively. The reforming or decomposition temperature is too high compared to the temperature preheated by evacuated tube collector, as a result, the $R$ s in Table 4 are small. Therefore, it is necessary to use concentrating solar collectors if $R$ is to be improved.

In the case of using hydrogen and air as heat transfer media, $Q^{\prime \prime}$ was calculated by Equation (6). When hydrogen is heated from the room temperature of $293 \mathrm{~K}$ to the operation temperature of PEFC system of $353 \mathrm{Kper}$ the mass of hydrogen in an evacuated tube collector, $Q^{\prime \prime}$ is $1.619 \mathrm{~kJ}$, which is equivalent to $M$ of $3.238 \times 10^{-5} \mathrm{~kg}$. When air is heated from the room temperature of $293 \mathrm{~K}$ to the operation temperature of PEFC system of 353 Kper the mass of air in an evacuated tube collector, $Q^{\prime \prime}$ is $1.671 \mathrm{~kJ}$, which is equivalent to $M$ of $3.342 \times 10^{-5} \mathrm{~kg}$. Similar to Table 4, Table 5 lists $Q^{\prime \prime}, M$ and $R$ in the case of using hydrogen and air as heat transfer media in the solar-hydrogen system. From Table 5, it can be seen that $R$ of hydrogen for January, April, July and October is $6.67 \%, 33.3 \%, 56.7 \%$ and $30.0 \%$, respectively, while $R$ of air for January, April, July and October is $23.3 \%, 55.0 \%, 96.7 \%$ and $46.7 \%$, respectively. When using hydrogen and air, the big effect of saving thermal energy was obtained. In summary, the proposed solar-hydrogen system is effective to provide heat to operate PEFC system.

In the case of using methane or ammonium as heat transfer media, the amount of hydrogen produced is calculated by the following equations:

$$
\begin{gathered}
\mathrm{CH}_{4}+\mathrm{H}_{2} \mathrm{O}=\mathrm{CO}_{2}+4 \mathrm{H}_{2} \\
2 \mathrm{NH}_{3}=\mathrm{N}_{2}+3 \mathrm{H}_{2}
\end{gathered}
$$


Table 4. Amount of heat needed from temperature preheated by evacuated tube collector to reforming or decomposition temperature $\left(Q^{\prime}\right)$, mass of utility gas needed $(M)$ and ratio of saving thermal energy $(R)$ for methane and ammonium.

\begin{tabular}{ccc}
\hline & Methane & Ammonium \\
\hline$Q^{\prime}$ (January) (kJ) & 26.36 & 20.18 \\
$Q^{\prime} \quad$ (April) (kJ) & 25.71 & 19.56 \\
$Q^{\prime}$ (July) (kJ) & 24.92 & 18.81 \\
$Q^{\prime}$ (October) (kJ) & 25.88 & 19.73 \\
$M$ (January) (kg) & $5.271 \times 10^{-4}$ & $4.036 \times 10^{-4}$ \\
$M$ (April) $(\mathrm{kg})$ & $5.141 \times 10^{-4}$ & $3.912 \times 10^{-4}$ \\
$M$ (July) $(\mathrm{kg})$ & $4.983 \times 10^{-4}$ & $3.761 \times 10^{-4}$ \\
$M$ (October) $(\mathrm{kg})$ & $5.175 \times 10^{-4}$ & $3.945 \times 10^{-4}$ \\
$R$ (January) (\%) & 1.67 & 2.06 \\
$R$ (April) $(\%)$ & 4.10 & 5.08 \\
$R$ (July) (\%) & 7.05 & 8.73 \\
$R$ (October) (\%) & 3.46 & 4.29 \\
\hline
\end{tabular}

Table 5. Amount of heat needed from temperature preheated by evacuated tube collector to operation temperature of PEFC system $\left(Q^{\prime \prime}\right)$, mass of utility gas needed $(M)$ and ratio of saving thermal energy $(R)$ for hydrogen and air.

\begin{tabular}{ccc}
\hline & Hydrogen & Air \\
\hline$Q^{\prime \prime}$ (January) (kJ) & 1.511 & 1.281 \\
$Q^{\prime \prime} \quad$ (April) $(\mathrm{kJ})$ & 1.080 & $7.521 \times 10^{-1}$ \\
$Q^{\prime \prime} \quad$ (July) $(\mathrm{kJ})$ & $7.017 \times 10^{-1}$ & $5.571 \times 10^{-2}$ \\
$Q^{\prime \prime}$ (October) (kJ) & 1.133 & $8.914 \times 10^{-1}$ \\
$M$ (January) $(\mathrm{kg})$ & $3.022 \times 10^{-5}$ & $2.562 \times 10^{-5}$ \\
$M$ (April) $(\mathrm{kg})$ & $2.159 \times 10^{-5}$ & $1.504 \times 10^{-5}$ \\
$M$ (July) $(\mathrm{kg})$ & $1.403 \times 10^{-5}$ & $1.114 \times 10^{-6}$ \\
$M$ (October) $(\mathrm{kg})$ & $2.267 \times 10^{-5}$ & $1.782 \times 10^{-5}$ \\
$R$ (January) $(\%)$ & 6.67 & 23.3 \\
$R$ (April) $(\%)$ & 33.3 & 55.0 \\
$R$ (July) $\%)$ & 56.7 & 96.7 \\
$R$ (October) $\%)$ & 30.0 & 46.7 \\
\hline
\end{tabular}

When the conversion ratio is assumed to be $100 \%$, the amount of hydrogen produced from methane and ammonium is $3.787 \mathrm{~mol}$ and $2.376 \mathrm{~mol}$, respectively. According to Equation (7), the power generated by PEFC system per effective area of anevacuated tube collector in the case of using methane or ammonium is $3.309 \times 10^{-2} \mathrm{kWh} / \mathrm{m}^{2}$ and $2.076 \times 10^{-2} \mathrm{kWh} / \mathrm{m}^{2}$, respectively. 
These performances are obtained for a day.

In the case of using hydrogen and air as heat transfer media, the amount of hydrogen in an evacuated tube collector is $1.882 \times 10^{-3} \mathrm{~kg}$, which is $9.410 \times 10^{-1} \mathrm{~mol}$. The amount of air is $2.769 \times 10^{-2} \mathrm{~kg}$, which is $9.558 \times 10^{-1}$ mol. According to Equation (7), 1/2 mol of oxygen is necessary per $1 \mathrm{~mol}$ of hydrogen. Therefore, $5 / 2 \mathrm{~mol}$ of air is necessary per $1 \mathrm{~mol}$ of hydrogen. Since the amount of hydrogen and air is $9.410 \times 10^{-1} \mathrm{~mol}$ and $9.558 \times 10^{-1} \mathrm{~mol}$, respectively, 3 units of evacuated tube collector are needed for the air to complete the chemical reaction with the hydrogen per an evacuated tube collector. Under this condition, the power generated by PEFC system per effective area of 4 units of evacuated tube collectors needed for heating hydrogen and air as mentioned above is $2.055 \times 10^{-3} \mathrm{kWh} / \mathrm{m}^{2}$. This performance is obtained for a day.

In Japan, the electric consumption of household per a day is $9 \mathrm{kWh}$ [40]. Therefore, 91 or 145 units, which have effective area of $273 \mathrm{~m}^{2}$ and $435 \mathrm{~m}^{2}$, respectively, of evacuated tube collector are necessary in the case of methane or ammonium, respectively. On the other hand, 1460 units, which has effective area of $4380 \mathrm{~m}^{2}$, of evacuated tube collector are necessary in the case of hydrogen and air. Consequently, it can be suggested that the evacuated tube collector having large effective area should be applied for solar-hydrogen system.

\section{Conclusions}

This study has investigated the performance of solar-hydrogen system when methane, ammonium, hydrogen, air or water is used as heat transfer media in the solar collector. The energy saving ratio of solar-hydrogen system to conventional utility gas heating only system has been calculated for each heat transfer media. The power generation performance of PEFC system has also been evaluated. As a result, the following conclusions have been drawn:

1) When methane, ammonium or air is used as heat transfer media, the temperature inside the collector depends on the horizontal solar radiation intensity strongly irrespective of seasons, and the highest temperature that they can reach are almost the same. The temperature response of hydrogen is slower than methane, ammonium or air namely reaches the peak temperature later during the day. When water is used as heat transfer media, the temperature is lower compared to the other heat transfer media irrespective of seasons. These results can be explained by the specific heat and mass of each heat transfer medium.

2) It has been found that the biggest thermal energy saving is obtained when hydrogen and air are used as the heat transfer media.

3) The power generated by PEFC system per effective area of an evacuated tube collector in the case of using methane or ammonium is $3.309 \times 10^{-2}$ $\mathrm{kWh} / \mathrm{m}^{2}$ and $2.076 \times 10^{-2} \mathrm{kWh} / \mathrm{m}^{2}$, respectively. On the other hand, the power generated by PEFC system per effective area of 4 units of evacuated tube collector is $2.055 \times 10^{-3} \mathrm{kWh} / \mathrm{m}^{2}$ in the case of using hydrogen and air. These performances are obtained for a day. 


\section{References}

[1] Bhosale, R., Kumar, A. and Almomani, F. (2016) Solar Thermochemical Hydrogen Production via Terbium Oxide Based Redox Reactions. International Journal of Photoenergy, 2016, Article ID: 9727895. https://doi.org/10.1155/2016/9727895

[2] Bulfin, B., Lange, M., Oliveria, L.D., Roeb, M. and Sattler, C. (2016) Solar Thermochemical Hydrogen Production Using Ceria Zirconia Solid Solutions: Efficiency Analysis. International Journal of Hydrogen Energy, 41, 19320-19328.

https://doi.org/10.1016/j.ijhydene.2016.05.211

[3] Bhosale, R., Kumar, A., Almomani, F. and Gupta, R.B. (2017) Solar Thermochemical $\mathrm{ZnO} / \mathrm{ZnSO}_{4}$ Water Splitting Cycle for Hydrogen Production. International Journal of Hydrogen Energy, 42, 23474-23483. https://doi.org/10.1016/j.ijhydene.2017.02.190

[4] Bhosale, R.R., Kumar, A., Almomani, F., Ghosh, U. and Khraisheh, M. (2017) A Comparative Thermodynamic Analysis of Samarium and Erbium Oxide Based Solar Thermochemical Water Splitting Cycles. International Journal of Hydrogen Energy, 42, 23416-23426. https://doi.org/10.1016/j.ijhydene.2017.03.172

[5] Alzahrani, A.A. and Dincer, I. (2016) Design and Analysis of a Solar Tower Based Integrated System Using High Temperature Electrolyzer for Hydrogen Production. International Journal of Hydrogen Energy, 41, 8042-8056. https://doi.org/10.1016/j.ijhydene.2015.12.103

[6] Monnerie, N., Storch, H.V., Houaijia, A., Roeb, M. and Sattler, C. (2017) Hydrogen Production by Coupling Pressurized High Temperature Electrolyser with Solar Tower Technology. International Journal of Hydrogen Energy, 42, 13498-13509. https://doi.org/10.1016/j.ijhydene.2016.11.034

[7] Ozcan, H. and Dincer, I. (2017) Energy and Exergy Analysis of a Solar Based Hydrogen Production and Compression System. International Journal of Hydrogen Energy, 42, 21414-21428. https://doi.org/10.1016/j.ijhydene.2017.05.001

[8] Rathod, V.P., Shete, J. and Bhale, P.V. (2016) Experimental Investigation on Biogas Reforming to Hydrogen Rich Syngas Production Using Solar Energy. International Journal of Hydrogen Energy, 41, 132-138. https://doi.org/10.1016/j.ijhydene.2015.09.158

[9] Jiang, D., Yang, W. and Tang, A. (2016) A Refractory Selective Solar Absorber for High Performance Thermochemical Steam Reforming. Applied Energy, 170, 286-292. https://doi.org/10.1016/j.apenergy.2016.02.121

[10] Liu, Q., Wang, Y., Lei, J. and Jin, H. (2016) Numerical Investigation of the Thermophysical Characteristics of the Mid-and-low Temperature Solar Receiver/Reactor for Hydrogen Production. International Journal of Heat and Mass Transfer, 97, 379-390. https://doi.org/10.1016/j.ijheatmasstransfer.2016.02.012

[11] Real, D., Dumanyan, I. and Hotz, N. (2016) Renewable Hydrogen Production by Solar-Powered Methanol Reforming. International Journal of Hydrogen Energy, 41, 11914-11924. https://doi.org/10.1016/j.ijhydene.2016.02.086

[12] Wang, Y., Liu, Q., Lei, J. and Jin, H. (2016) A Three-Dimensional Simulation of a Mid-and-Low Temperature Solar Receiver/Reactor for Hydrogen Production. Solar Energy, 134, 273-283. https://doi.org/10.1016/j.solener.2016.05.003

[13] Nakajima, H., Lee, D., Lee, M.T. and Grigoropoulos, C.P. (2016) Hydrogen Production with $\mathrm{CuO} / \mathrm{ZnO}$ Nanowire Catalyst for a Nanocatalytic Solar Thermal Steam-Methanol Reformer. International Journal of Hydrogen Energy, 41, 16927-16931. https://doi.org/10.1016/j.ijhydene.2016.07.039 
[14] Wang, Y., Liu, Q., Sun, J., Lei, J., Ju, Y. and Jin, H. (2017) A New Solar Receiver/Reactor Structure for Hydrogen Production. Energy Conversion and Management, 133, 118-126. https://doi.org/10.1016/j.enconman.2016.11.058

[15] Wang, J., Wu, J., Xu, Z. and Li, M. (2017) Thermodynamic Performance Analysis of a Fuel Cell Trigeneration System Integrated with Solar-Assisted Methanol Reforming. Energy Conversion and Management, 150, 81-89.

https://doi.org/10.1016/j.enconman.2017.08.012

[16] Kalogirou, S.A., Karellas, S., Braimakis, K. and Stanciu, C. (2016) Exergy Analysis of Solar Thermal Collectors and Process. Progress in Energy and Combustion Science, 56, 106-137. https://doi.org/10.1016/j.pecs.2016.05.002

[17] Yang, J., Jiang, Q., Hou, J. and Luo, C. (2015) A Study on Thermal Performance of a Novel All-Glass Evacuated Tube Solar Collector Manifold Header with an Inserted Tube. International Journal of Photoenergy, 2015, Article ID: 409517. https://doi.org/10.1155/2015/409517

[18] Paradis, P.L., Rousse, D.R., Halle, S., Lamarche, L. and Quesada, G. (2015) Thermal Modeling of Evacuated Tube Solar Air Collectors. Solar Energy, 115, 708-721. https://doi.org/10.1016/j.solener.2015.03.040

[19] Pitatheepan, M. and Anderson, T.N. (2015) Natural Convection Heat Transfer in Façade Integrated Solar Concentrators. Solar Energy, 122, 271-276. https://doi.org/10.1016/j.solener.2015.09.008

[20] Zheng, W., Zhang, H., You, S., Fu, Y. and Zheng, Z. (2017) Thermal Performance Analysis of a Metal Corrugated Packing Solar Air Collector in Cold Regions. Applied Energy, 203, 938-947. https://doi.org/10.1016/j.apenergy.2017.06.016

[21] Hung, T.C., Huang, T.J., Lee, D.S., Lin, C.H., Pei, B.S. and Li, Z.Y. (2017) Numerical Analysis and Experimental Validation of Heat Transfer Characteristic for Flat-Plate Solar Air Collector. Applied Thermal Engineering, 111, 1025-1038. https://doi.org/10.1016/j.applthermaleng.2016.09.126

[22] Arkar, C. and Medved, S. (2015) Optimization of Heat Storage in Solar Air Heating System with Vacuum Tube Air Solar Collector. Solar Energy, 111, 10-20. https://doi.org/10.1016/j.solener.2014.10.013

[23] Guldentops, G. and Dessel, S.V. (2017) A Numerical and Experimental Study of a Cellular Passive Solar Façade System for Building Thermal Control. Solar Energy, 149, 102-113. https://doi.org/10.1016/j.solener.2017.03.078

[24] Delfani, S., Karami, M. and Akhavan-Behabadi, M.A. (2016) Performance Characteristics of a Residential-Type Absorption Solar Collector using MWCNT Nanofluid. Renewable Energy, 87, 754-764. https://doi.org/10.1016/j.renene.2015.11.004

[25] Colangelo, G., Favale, E., Miglietta, P., Milanese, M. and Laforgia, D. (2015) Experimental Test of an Innovative High Concentration Nanofluid Solar Collector. Applied Energy, 154, 874-881. https://doi.org/10.1016/j.apenergy.2015.05.031

[26] Karami, M., Akhavan-Bahabadi, M.A., Delfani, S. and Raisee, M. (2015) Experimental Investigation of $\mathrm{CuO}$ Nanofluid-Based Direct Absorption Solar Collector for Residential Applications. Renewable and Sustainable Energy Reviews, 52, 793-801. https://doi.org/10.1016/j.rser.2015.07.131

[27] Coccia, G., Nicola, G.D., Colla, L., Fedele, L. and Scattolini, M. (2016) Adoption of Nanofluids in Low-Enthalpy Parabolic Trough Solar Collectors: Numerical Simulation of the Yearly Yield. Energy Conversion and Management, 118, 306-319. https://doi.org/10.1016/j.enconman.2016.04.013

[28] Edalatpour, M. and Solano, J.P. (2017) Themal-Hydraulic Characteristics and Ex- 
ergy Performance in Tube-on-Sheet Flat Plate Solar Collectors: Effects of Nanolfuids and Mixed Convection. International Journal of Thermal Science, 118, 397-409. https://doi.org/10.1016/j.ijthermalsci.2017.05.004

[29] Chubu Electric Power (2014) The Irradiance Data of the Project "PV300" (Electric Data Base).

[30] Terada Tekkosyo (2017). https://www.2.solars.jp

[31] Nippon Avionics Co., Ltd. (2017). http://www.avio.co.jp/products/infrared/support/thermo/technical/emissivity.html

[32] Holman, J.P. (1992) Heat Transfer. 7th Edition, McGraw-Hill Book Company, London, 268.

[33] Hasatani, M., Kimura, J., Arai, N. and Sato, A. (1988) Basis and Application of Combustion. 2nd Edition, Kyoritsu Syuppan, Tokyo, 270.

[34] Mundhwa, M. and Thurgood, C.P. (2017) Methane Steam Reforming at Low Steam to Carbon Ratios over Alumina and Yttria-stabilized-zirconia Supported Nickel-Spinel Catalyst: Experimental Study and Optimization of Microkinetic Model. Fuel Processing Technology, 168, 27-39. https://doi.org/10.1016/j.fuproc.2017.08.031

[35] Jeon, Y., Kim, H., Lee, C., Lee, S., Song, S. and Shul, Y.G. (2017) Efficient Methane Reforming at Proper Reaction Environment for the Highly Active and Stable Fibrous Perovskite Catalyst. Fuel, 207, 493-502. https://doi.org/10.1016/j.fuel.2017.06.113

[36] Yuan, Q., Gu, R., Ding, J. and Lu, J. (2017) Heat Transfer and Energy Storage Performance of Steam Methane Reforming in a Tubular Reactor. Applied Thermal Engineering, 125, 633-643. https://doi.org/10.1016/j.applthermaleng.2017.06.044

[37] Matsuno, K. and Saika, T. (2016) Research of an Ammonia Decomposition Hydrogen Supply System. Proceedings of Conference of Japan Institute of Energy, 286-287.

[38] Sezgin, B., Caglayan, D.G., Devrim, Y., Steenberg, T. and Eroglu, I. (2016) Modeling and Sensitivity Analysis of High Temperature PEM Fuel Cells by using Comsol Multiphysics. International Journal of Hydrogen Energy, 41, 10001-10009. https://doi.org/10.1016/j.ijhydene.2016.03.142

[39] Panasonic (2017) Specification of ENEFARM. https://panasonic.co.jp/ap/FC/about_01.html

[40] The Federation of Electric Power Companies of Japan (2018). http://www.fepc.or.jp/enterprise/jigyou/japan/sw_index04/ 